\title{
Convention on the Rights of the Child: children and teenagers' labor in debate (1978-1989)
}

\begin{abstract}
This article aims to describe and analyze how the debate about labor relations in the field of childhood, adolescence, and youth was framed during the construction of the Convention on the Rights of the Child by member countries of the United Nations (UN) and non-governmental organizations (NGOs) between 1978 and 1989. It also seeks to provide information on the presence of the legal discourse contained in this international law agreement in the Brazilian legislation for children, teenagers, and young people enacted in the country in the year 1990.
\end{abstract}

\section{Silvia Maria Fávero Arend}

Ph.D. in History from the Federal University of Rio Grande do Sul (UFRGS). Professor at the

Department of History and the Graduate Program in History of the Santa Catarina State University (UDESC).

Florianópolis - SC - BRAZIL

smfarend@gmail.com orcid.org/0000-0002-3262-5596

Keywords: History; Childhood; Youth; Rights; Labor Relations.

DOI: $10.5965 / 2175180311272019608$

http://dx.doi.org/10.5965/2175180311272019608

\footnotetext{
* Translation of the article "Convenção sobre os Direitos da Criança: em debate o labor infantojuvenil (1978-1989)" published in the Journal Tempo e Argumento, Florianópolis, v. 7, n. 14, p. 29-47, jan./abr. 2015. http://dx.doi.org/10.5965/2175180307142015029

** Translator: Evandro L. Freire
} 


\title{
Convenção sobre os Direitos da Criança: em debate o labor infantojuvenil (1978-1989)
}

\begin{abstract}
Resumo
Resumo

Este artigo tem por objetivo descrever e analisar como se processou o debate acerca das relações de trabalho no campo da infância, adolescência e juventude durante a construção da Convenção sobre os Direitos da Criança pelos países-membros da Organização das Nações Unidas (ONU) e organizações não governamentais (ONG) entre 1978 e 1989. Busca-se, também, apresentar informações sobre a presença do discurso jurídico dessa normativa internacional na legislação brasileira para as crianças, adolescentes e jovens instituída no país no ano de 1990.
\end{abstract}

Palavras-chave: História; Infância; Juventude; Direitos; Relações de Trabalho.

\section{Introduction}

Although a significant portion of society does not recognize them, within the last 30 years in Brazil', there have been changes regarding childhood, especially among the poorest social strata and those in precarious conditions. In this period, this population segment is no longer perceived only as a social problem, it has gradually become integrated by subjects of rights. This movement, whose exponent was the legislation enacted in 1990, named as the Brazilian Child and Teenager Statute (Estatuto da Criança e do Adolescente - ECA), had as its leading figures a set of social players, namely: poor families, law practitioners in Brazil, the technical and bureaucratic body that formulated social policies and the other body working in institutions for shelter and/or imprisonment, social movement activists (Minor's Pastoral Catholic Church, Children's Pastoral Catholic Church, Homeless Boys and Girls Movement, etc.), and representatives of international organizations ${ }^{2}$.

\footnotetext{
${ }^{1}$ In this article, the word childhood is used to refer to the female and male population aged between 0 and 21 years.

${ }^{2}$ BRASIL. Lei número 8.069, de 13 de julho de 1990.
} 
In this article, we analyze how Article 32 of the Universal Convention on the Rights of the Child has been built, whose theme is economic exploitation and children and teenagers' labor ${ }^{3}$. The document, produced by the non-governmental organization (NGO) Save the Children, named as the 'Legislative History of the Convention on the Rights of the Child,' provides this study with a basis. This two-volume document describes the debates occurring from 1978 to 1989 between the diplomatic corps of the various nations constituting the United Nations (UN) and NGOs concerning the themes addressed by the Universal Convention on the Rights of the Child. We also seek to verify how the 'echoes' of formulations contained in the above mentioned international law agreement had repercussions in the Brazilian legislation enacted in $1990^{4}$.

\section{On the Convention on the Rights of the Child}

During the 1980s, the UN promoted a long debate between its member States and other political and economic entities in order to produce a document based on the human rights ideals for the children and teenagers population (OESTREICH, 1998). That body had been founded in 1945, in an attempt to create a global international entity promoting dialogue, since its predecessor, the League of Nations, proved ineffective in failing to prevent the outbreak of a new World War, in 1939. The creation of the Universal Declaration of Human Rights, in 1948, is regarded as one of the most important achievements of this international institution. The universal nature of the declaration would be strengthened by its unqualified approval or dissenting votes among the member countries. According to Flávia Piovesan (2013), the Universal Declaration of Human Rights interconnects the liberal discourse and the social discourse of citizenship, adding the value freedom to the value equality.

In relation to the universe of children and teenagers, two international law agreements had already been produced in the $20^{\text {th }}$ century. The first was drawn up in 1923

\footnotetext{
3 ORGANIZAÇÃO DAS NAÇÕES UNIDAS. Convenção sobre os Direitos da Criança, de 20 de novembro de 1989.

${ }^{4}$ This article derives from the study entitled 'Childhood, law, and citizenship (Brazil, 1980-1990),' conducted during a Post-Ph.D. internship at the Fondation Nationale des Sciences Politiques (Science Po) Paris/France. The research has been funded by the Brazilian Coordination for the Improvement of Higher Education Personnel (CAPES)/Ministry of Education (MEC).
} 
prepared in 1959 by the UN, although with some significant changes. This is what Gustavo Ferraz de Campos Monaco (2005, p. 128, our translation) claims about this document:

The main point of this statement (Resolution No. 1,386), in relation to its predecessor in the protection of childhood, is the paradigm shift it sets up, much in the wake of the consolidation of the 1948 Declaration that universalizes the protection of human rights, since now the child comes to be seen as a subject of rights and no longer as a mere passive recipient of actions carried out in her/his favor, beginning to apply a principle that thirty years later would be inserted in the subsequent convention, which is the principle of the best interest for the child.

The Convention on the Rights of the Child, prepared with participation of Brazil's diplomatic representatives, was approved in $1989^{5}$. This international law agreement began to be drafted in 1978, starting with an initial text presented by the representatives of the government of Poland to the UN. In this early text, the precepts of human rights applied to the universe of children and teenagers were expressed. Over 10 years, diplomatic representatives of the member countries of the UN and NGOs discussed the themes introduced in the initial text, as well as other supplementary issues. This debate, as mentioned above, was compiled in the document organized by the NGO Save the Children, providing this investigation with means ${ }^{6}$.

In this international law agreement, we see human rights expressed within a homogeneous scope, i.e. those recommended for the general population, regardless of the age group, and those within a heterogeneous reach, which are specific for individuals categorized as minor. The legal principles of homogenous rights reaffirmed during childhood are: equality, understanding, development, freedom, dignity, and physical, mental, and moral integrity. According to Gustavo Ferraz de Campos Monaco (2005, p. 148), guaranteeing these rights for children will enable them, when entering into adulthood, to achieve full citizenship.

${ }^{5}$ ORGANIZAÇÃO DAS NAÇÕES UNIDAS. Convenção sobre os Direitos da Criança, de 20 de novembro de 1989.

${ }^{6}$ Office of the United Nations High Commissioner for Human Rights. Legislative History of the Convention on the Rights of the Child, Save the Children, 2007. 
Among the rights within a homogeneous reach, those exercisable during the life stage called childhood stand out, i.e. the right to food, education, health, nationality, and a name and a patronymic name. Failure to guarantee these homogenous rights, from the human rights perspective, can lead to serious problems in the future life of a particular person, either at the biological or sociocultural level or, also, in the field of political rights.

The right to family life, the right to not work, the right to protection and help in times of extreme difficulties and needs, and the rights of children who are considered disabled are the so-called rights within a heterogeneous reach. The introduction/implementation of this set of rights, based on the human rights ideals, possibly causes changes in practices and values that have been carried out for a long time by various social players in various societies, such as the State, families, public and private institutions for shelter, etc. Among the rights within a heterogeneous reach, the right to not work is associated with a children's socialization perspective, teenagers and young people from another perspective, the school's. The introduction of this right, regarded by many as radical, implies significant changes in current social practices, as demonstrated below.

\section{On the scene debates on children and teenagers' labor}

It was observed that, among the rights having a heterogeneous nature, issues related to children, teenagers, and young people's labor have aroused debates in the process of making the Convention on the Rights of the Child. It is worth considering these discussions, which took place over 10 years, i.e. between 1978 and 1989. In the document produced by the NGO Save the Children there is no record of expert opinions issued by the diplomatic representatives of Brazil concerning this theme, unlike other times in the making of this agreement, such as the preparation of Article 20, which deals with 'Family Life,' where the diplomatic corps of Brazil manifested effectively in the process of drafting this international law agreement.

These debates on children and teenagers' labor took place in the process of making Article 32, in the aforementioned legislation, which has the final wording shown below, voted on November 20, 1989, at the United Nations General Assembly: 
1. States Parties recognize the right of the child to be protected from economic exploitation and from performing any work that is likely to be hazardous or to interfere with the child's education, or to be harmful to the child's health or physical, mental, spiritual, moral or social development.

2. States Parties shall take legislative, administrative, social and educational measures to ensure the implementation of the present article. To this end, and having regard to the relevant provisions of other international instruments, States Parties shall in particular:

(a) Provide for a minimum age or minimum ages for admissions to employment;

(b) Provide for appropriate regulation of the hours and conditions of employment;

(c) Provide for appropriate penalties or other sanctions to ensure the effective enforcement of the present article (Office of the United Nations High Commissioner for Human Rights. Legislative History of the Convention on the Rights of the Child, Save the Children, 2007, p. 693)7.

The first wording that gave rise to Article 32, proposed in 1978, by representatives of the Government of Poland, was:

1. The child shall be protected against all forms of neglect, cruelty and exploitation. He shall not be the subject of traffic, in any form.

2. The child shall not be admitted to employment before an appropriate minimum age; he shall in no case be caused or permitted to engage in any occupation or employment which would prejudice his health or education, or interfere with his physical, mental or moral development (Office of the United Nations High Commissioner for Human Rights. Legislative History of the Convention on the Rights of the Child, Save the Children, 2007, p. 693) ${ }^{8}$.

It was found that, in the initial wording of the international law agreement proposed by the Government of Poland, the first paragraph addressed issues concerning

7 1. Os Estados Partes reconhecem à criança o direito de ser protegida contra a exploração econômica ou a sujeição a trabalhos perigosos ou capazes de comprometer a sua educação, prejudicar a sua saúde ou o seu desenvolvimento físico, mental, espiritual, moral ou social.

2. Os Estados Partes tomam medidas legislativas, administrativas, sociais e educativas para assegurar a aplicação deste artigo. Para esse efeito, e tendo em conta as disposições relevantes de outros instrumentos jurídicos internacionais, os Estados Partes devem, nomeadamente:

(a) Fixar uma idade mínima ou idades mínimas para a admissão a um emprego;

(b) Adotar regulamentos próprios relativos à duração e às condições de trabalho;

(c) Prever penas ou outras sanções adequadas para assegurar uma efetiva aplicação deste artigo.

8 1. A criança será protegida contra toda forma de negligência, exploração ou crueldade. Ela não será sujeita ao tráfico de crianças, independente do seu fim ou forma.

2. A criança não será admitida a um emprego antes da idade mínima apropriada; ela não terá permissão de se engajar em quaisquer trabalhos perigosos ou capazes de comprometer sua educação, prejudicar sua saúde ou o seu desenvolvimento físico, mental, espiritual, moral ou social. 
the trafficking of children who would possibly enter the labor market. During the debates on children and teenagers' labor, this theme was no longer mentioned by any of the countries or non-governmental entities. In the final wording of the international law agreement, Article 35 refers to trafficking of people. Another major issue to mention refers to the location of the theme children and teenagers' labor in the agreement. In the early proposition, the issue was dealt with in Article 9. Subsequently, during the 10-year debates, the theme was dealt with in Article 18. In the final wording of the international document, the theme was addressed in Article 32.

Between the initial and the final wording of Article 32, we notice a concern of lawmakers in regulating children and teenagers' labor in relation to 3 issues. The first concerns the age at which the child can enter the labor market. In general, the diplomatic corps of many countries and non-governmental institutions suggested that boys and girls could start working when they reached the age of 14 years. Only the International Labour Organization (ILO), as we show later, did not advocate at what age should the child be. Finally, in the international agreement, the age of 14 years did not remain expressed in the letter of the law. Lawmakers preferred to allow each country, in view of the local scenario, to set a minimum age for initiating this process.

The other issue refers to the number of hours working, as well as the spaces/settings where children, teenagers, and young people could work. According to the makers of international law, each country needed to regulate these 2 issues considered of vital importance in the course of debates. New Zealand's diplomatic corps, in order to demonstrate in which sectors of the economy minors of both sexes no longer worked in their country, described how the regulation of children and teenagers' labor took place during the $20^{\text {th }}$ century in that society. In 1908 , boys under the age of 14 years and girls under the age of 16 years were restrained from begging and selling alcoholic beverages on the streets of towns and villages. Later, in 1925, minors under the age of 14 years were prohibited from working in coal mines and, in 1939, those under the age of 18 years could not work in the oil sector. Since 1946, people of both sexes under the age of 15 years could no longer enter factories as workers. In the 1950s, a set of laws no longer allowed young people under the age of 15 years to operate large-sized machines. In the 
reaching this scenario regarded as 'ideal,' the New Zealand State had faced many obstacles, especially in relation to the agricultural sector, which used family labor. Concurrently with the ban on such work, school education has become compulsory for all boys and girls in New Zealand?.

On the basis of a proposal made by the United Kingdom's diplomatic corps, the Convention on the Rights of the Child introduced the need to impose sanctions for persons/families/businesses that did not comply with the provisions of the first 2 paragraphs of Article 32. In other words, if necessary, the States ratifying such agreement should punish those who benefit from children and teenagers' labor.

Many non-governmental institutions representing women - the International Council of Women, the International Council of Jewish Women, the International Federation of Women in Legal Careers, and the International Federation of Women Lawyers - participated in the debate on children and teenagers' labor. Among these NGOs, the International Federation of Women in Legal Careers stands out, which declared to be in favor of punishment for those who stood against children's health through domestic violence and drug use ${ }^{10}$.

The number of countries that emphatically engaged in the process of drafting the international law agreement on children and teenagers' labor has not been large: New Zealand, the United States of America, the United Kingdom, the German Democratic Republic, the Federal Republic of Germany, Canada, Finland, and Suriname were among those outstanding. In general, there was a consensus among lawmakers from these countries and NGOs concerning the prospect of regulating children and teenagers' labor. This regulation, to a large extent, made no distinction between the sexes of children.

\footnotetext{
${ }^{9}$ Office of the United Nations High Commissioner for Human Rights. Legislative History of the Convention on the Rights of the Child, Save the Children, 2007, p. 694-696.

${ }^{10}$ Office of the United Nations High Commissioner for Human Rights. Legislative History of the Convention on the Rights of the Child, Save the Children, 2007, p. 701.
} 
The dissonant 'voice' in this debate was that of the ILO. At 2 points in the discussions, the ILO representatives came up against the use of Convention No. 5, enacted in 1921, in the process of defining minimum age for children's entry in the labor market. This convention, adopted in the beginning of the $20^{\text {th }}$ century, advocated 14 years as the minimum age to allow the entry of people of both sexes in activities of the industrial sector. For the members of this entity, the debate on children and teenagers' labor should be based on the provisions of Convention No. 138, approved in June $1973^{11}$. This is what the ILO representatives claimed:

The Convention makes provision for the pursuit of a national policy aimed at the abolition of child labour and the progressive raising of the minimum age for admission to employment or work to a level consistent with the fullest physical and mental development of young persons. It establishes different age levels for admission to employment in general, for employment dangerous to health, safety or morals, and for light work under specified conditions, and introduces various other elements of flexibility in regulating these matters (Office of the United Nations High Commissioner for Human Rights. Legislative History of the Convention on the Rights of the Child, Save the Children, 2007, p. 700, our emphasis) $)^{12}$.

The ILO advocated the abolition of children and teenagers' labor in the various countries based on policies formulated by the national States. Perhaps a proposal regarded as radical by many members of the diplomatic corps, since children and teenagers' workforce, especially in countries where family farming has been the 'engine' of the economy, was of crucial significance. This entity also did not prescribe a minimum age for children to enter the labor market. According to the ILO members, indeed, the economic sector - agriculture, trade, industry, and services -, with its specific features or characteristics, determines this 'flexible' minimum age between 14 and 18 years. This process would also be distinctive for countries whose economy and educational institutions were not sufficiently 'developed,' yet, and for the countries where this

11 ORGANIZAÇÃO INTERNACIONAL DO TRABALHO. Convenção Número 138 sobre a idade mínima de admissão ao emprego, de 06 de junho de 1973.

${ }^{12}$ A Convenção (número 138) prevê a prossecução de uma política nacional para a abolição do trabalho infantil e o aumento progressivo da idade mínima para admissão a emprego ou trabalho a um nível compatível com o pleno desenvolvimento físico e mental dos jovens. Ela estabelece diferentes níveis de idade para admissão ao emprego, em geral, para o emprego perigoso para a saúde, segurança ou moral, e para os trabalhos leves sob condições específicas e introduz vários outros elementos de flexibilidade para regulamentar essas matérias. 
process had already taken place. In the final wording of the international law agreement, the ILO proposal prevailed at least in part, since the minimum age of 14 years was not stipulated.

The notion of bourgeois childhood has as one of its primary premises the assertion that the child is a human being in formation. From this perspective, the production of a healthy child's body is key, especially when this population needs to work. The representatives of the Food and Agriculture Organization of the United Nations (FAO), during the debate on children and teenagers' labor, raised special concerns with regard to the feeding of boys and girls. It is worth mentioning that the entity representatives stated that it was necessary to fight against the discrimination existing in many societies concerning the poor feeding provided to the girls. For this institution, the child, teenager, and young person's diet consisted in a right that should be guaranteed through social policies of national scope. The excerpt below is part of the proposal made by FAO representatives in the discussions:

Three aspects should be considered in the definition of the child's right to food. The State Parties should:

(a) Recognize the children's right to food and the significance of food culture as part of a wider cultural identity (national obligation to respect the right to food).

(b) Prevent distortion of positive nutritional aspects of existing food patterns and develop national legislation and administrative mechanisms and procedures to protect and facilitate a valid food procurement for all children (national obligation to protect the right to food).

(c) Incorporate nutritional considerations into relevant development activities and formulate and execute policies, plans and programmes to facilitate and assist children in obtaining viable food procurement (national obligation to fulfill the right to food) (Office of the United Nations High Commissioner for Human Rights. Legislative History of the Convention on the Rights of the Child, Save the Children, 2007, p. 706) ${ }^{13}$.

${ }^{13}$ Três aspectos devem ser considerados na definição dos direitos da criança ao alimento. Os Estados Partes devem:

(a) Reconhecer o direito da criança ao alimento, e ao significado da cultura alimentar como parte de uma cultura identitária maior (obrigação nacional de respeitar o direito à alimentação).

(b) Prevenir a distorção de possíveis aspectos nutricionais de padrões alimentares existentes e mecanismos administrativos com procedimentos para proteger e facilitar uma licitação alimentar válida para toda criança (obrigação nacional de proteger o direito à alimentação).

(c) Incorporar considerações nutricionais em atividades de desenvolvimento relevantes, formulando e executando políticas, planos e programas para facilitar e dar assistência a crianças na obtenção de licitações para alimentação viável (obrigação nacional de cumprir o direito à alimentação). 
Finally, the fact that members of the United Nations Children's Fund (UNICEF) were very shy in their discussions over the decade on children and teenagers' labor. Its representatives ratified what the ILO in relation to Convention No. 138 and, in order to achieve these purposes, national States should take legislative, administrative, social, and educational measures.

\section{Echoes of debates on the Convention on the Rights of the Child in Brazilian legislation}

The 'echoes' of these debates in the international legal field reached the Brazilian society mainly through the UNICEF representatives who worked in Brazil along with institutions for the 'needy minors,' in the 1970 s and 1980s. These professionals disseminated in the media printed a discourse about the problems faced by poor childhood in the country (OLIVEIRA, 2008). This discourse was often based on information from social reports made by foreign NGOs affiliated with the UN on Brazilian childhood issues (BETHOUX, 2011) ${ }^{14}$.

Since the beginning of the 2oth century, sons and daughters of poor families were considered a social problem in Brazil. However, in some historical moments, this issue has gained greater momentum and new contours. The Brazilian society, in the 1970s, was undergoing an intense urbanization process. Populations from small towns and rural areas migrated to mid- and large-size urban centers in search of better living conditions, seen, above all, as a possibility of access to work, social mobility, and modern consumption. According to the Brazilian Institute of Geography and Statistics (IBGE), in the early 1980s, Brazil had 82,013,375 inhabitants living in the urban area and 39,137,198 in the rural $a \mathrm{area}^{15}$. The period of the so-called 'economic miracle' and its consequences, based on the modernization of the country's infrastructure and the development of the industrial and service sectors, was marked by the creation of a large army of low-wage urban workers. Some of the population that migrated to cities managed to climb the dreamed social ladder and reached the family income of formal workers, suburb's

\footnotetext{
${ }^{14}$ See, for instance: FÉDÉRATION INTERNATIONALE DES DROITS DE L'HOMME. Rapport de Mission. La prostitution des enfants au Brésil. Bibliothèque des Sciences Po - Paris.

15 INSTITUTO BRASILEIRO DE GEOGRAFIA E ESTATÍSTICA. Censo demográfico de 1980. População recenseada.
} 
inhabitants, with some legal guarantees and access to certain public services. Another part of this population remained or became impoverished and began to inhabit precarious and generally irregular urban settlements, in allotments located in peripheric areas or hills, in what is known as favelas in Brazil.

The socialization of children, teenagers, and young people by means of work relations has become, throughout the historical evolution of Brazilian society, almost a rule for poor girls and boys in the rural and urban world. In the 1970s, the context of widespread children and teenagers' labor practices remained broadly unchanged in urban centers, especially for migrant populations. Due to the low income earned by mothers, fathers, and other relatives in their professional activities, girls and boys were forced to enter the formal and informal labor markets. Gradually, activities in the informal labor market, such as drug trafficking, sexual exploitation, and begging, started being pursued by a larger proportion of poor children and teenagers. For the Brazilian State representatives, this situation has gradually become increasingly serious. In 1976, the Brazilian House of Representatives established the so-called Parliamentary Commission of Investigation on Minors, which resulted in the preparation of a 669-page document, providing means to the State representatives' actions in relation to the current situation, as well as to the formulation of legislation for children and young people implemented within the period, the 1979 Brazilian Minors Code ${ }^{16}$.

The 1979 Brazilian Minors Code was drafted having the legal doctrine of the irregular situation as a basis. The absence of practices and values related to the bourgeois family type characterized the irregular situation in the case of children categorized as abandoned and offenders. Unlike the 1927 Brazilian Minors Code ${ }^{17}$, this new legislation did not typify cases in which Brazilian judicial authorities could withdraw and/or suspend the legal institute of mothers, fathers or other relatives' custody (AREND; DAMINELLI, 2014). Thus, in the period, a significant amount of children, teenagers, and young people was sent to the shelters, having as justification only the poverty of their family. On the other hand, poor families who sought the survival of their offspring petitioned juvenile judges so that their sons and daughters had a place in the shelters.

\footnotetext{
${ }^{16}$ BRASIL. Lei número 6.697, de 10 de outubro de 1979.

${ }^{17}$ BRASIL. Decreto número 17. 943-A, de 12 de outubro de 1927.
} 
The 1979 Brazilian Minors Code addressed the issue of children and teenagers' labor only in 1 article in Title VIII, entitled 'On the Minors' Labor.' Article 83 of the aforementioned law stated: "The protection of minor labor is regulated by special legislation,' i.e. by the Brazilian Consolidation of Labor Laws (CLT) (Articles 402 to 441), sanctioned in 1943, by President Getúlio Vargas. According to rulers of that period, the fact that a population contingent entered the formal and informal labor market since childhood was not an issue that should be dealt with under the 'minor's' legislation.

In 1964, the same year of the coup d'État that imposed the military dictatorship, the new rulers of the nation instituted the Brazilian National Foundation for the WellBeing of Minors (FUNABEM), responsible for social policies deployed in the country for around 15 years, especially for children categorized as offenders. The assumptions of the Brazilian National Security Doctrine, drafted in the Brazilian Superior School of War, allied to the maxim of social prevention, guided the actions of the public power (BASÍLIO, 1985). Large centers for the reclusion and rehabilitation, mainly for male individuals accused of committing offenses, were created in the various states of the Brazilian Federation. These social restraint institutions were managed by a regional 'branch' of FUNABEM installed in each Brazilian state. Gradually, complaints about the violence inflicted on teenagers and young people in these institutions began to surface through the press and civil entities, such as the Brazilian Bar Association (OAB). In the subsequent decades, the institutions for reclusion of teenagers and young people became synonymous with human rights violations in the country (VOGEL, 2001; FRONTANA, 1999).

This scenario with 'dark colors' regarding the Brazilian childhood perceived as offending and abandoned began to be put into question in the early 1980s. A set of voices, mostly in a denouncing tone, began to manifest in relation to what happened with children, teenagers, and young people. According to Marcos Napolitano (2002, p. 145162), "the 'language of rights' seems to have guided discourses within the period, in spite of the various ideological nuances."

A significant part of the debates, especially by the press, about the 'problem' of Brazilian childhood, had within its horizon the introduction of the legal notion of subject 
of rights, based on the human rights ideals. This legal notion, regarded as revolutionary by many, took the main focus out of the civil society and the State that, since the first legislation for childhood drafted by the Brazilian republicans in 1927, was characterized by being 'adult-centric.' Then, bringing the interests of children, teenagers, and young people to the foreground meant putting into question power relations established for a long time between the adult and the children and teenagers' universes, 'embodied' in the civil, criminal, and childhood legislation (SANDRINI, 2009).

In 1990, the Brazilian State enacted the ECA at the federal level. This legislation was instituted only 1 year after the Convention on the Rights of the Child was approved by the UN. It is understood that a significant part of debates that took place during the years 1978 and 1989 was incorporated in the Brazilian legislation. Title II of the ECA, addressing the so-called 'Fundamental Rights,' refers to life and health; freedom, respect, and dignity; family and community life; education, culture, sport, and leisure; and professionalization and protection at work.

Chapter V, entitled "On the Right to Professionalism and Protection at Work," seeks to regulate children and teenagers' labor from the viewpoint of rights, along with the labor legislation in force in Brazil since the 1940s, referred to above ${ }^{18}$. The themes addressed in Article 32 of the Convention on the Rights of the Child, such as the delimitation of the age group for entering the labor market (14 years) and the prohibition of hours and places for the performance of work activities, are addressed by the ECA in Articles 60 and 67 , as shown below:

Art. 60 - Any work under the age of fourteen years, except as an apprentice, is prohibited.

Art. 67 - The adolescent employee, apprentice, under the family work regime, technical school student, assisted by a governmental or nongovernmental entity, should not engage in work:

I - at night, performed between 10 p.m. and 5 a.m.;

II - dangerous, unhealthy, or distressing;

III - carried out in places detrimental to their upbringing and to their physical, psychic, moral, and social development;

IV - carried out at times and places that prevent school attendance ${ }^{19}$.

\footnotetext{
${ }^{18}$ BRASIL. Lei número 8.069, de 13 de julho de 1990. Capítulo V, Art. 60 - Art. 69.

${ }^{19}$ BRASIL. Lei número 8.069, de 13 de julho de 1990. Capítulo V, Art. 60 - Art. 67.
} 
Finally, the 'official' history of the ECA claims that this piece of legislation is the result, above all, of debates that took place between Brazilian law practitioners during the redemocratization period. This study tries to demonstrate that the discourses of international organizations were also of key importance so that the 'letter' of the law could find a certain shape. This imbrication between discourses at the local/national and international levels may explain, in part, why the application of this piece of legislation to the Brazilian children and adolescent population generated and still generates so much resistance on the part of several social segments.

\section{References}

AGAMBEN, Giorgio. Homo Sacer. O poder soberano e a vida nua. Belo Horizonte: Ed. UFMG, 2004. v.1.

ALANEN, Leena. Estudos feministas/estudos da infância: paralelos, ligações e perspectivas. In: CASTRO, Lucia Rabello (Org.). Crianças e jovens na construção da cultura. Rio de Janeiro: Nau, 2001. p. 69-92.

AREND, Silvia Maria Fávero; DAMINELLI, Camila Serafim. Políticas sociais para infância e juventude carente e infratora (1970-1980). In: BRANCHER, Ana Lice; LOHN, Reinaldo Lindolfo (Org.). Histórias na ditadura: Santa Catarina (1964-1985). Florianópolis: Ed. UFSC, 2014. p. 181-205.

ARIÈS, Philippe. História social da criança e da família. Rio de Janeiro: LTC, 1981.

BASÍLIO, Luiz Cavalieri. O menor e a ideologia de segurança nacional. Belo Horizonte: Veja-Novo Espaço, 1985.

BETHOUX, Camille. La promotion des normes internationales des droits humains: le rôle de la Fédération Internationale des Droits de l'Homme (FIDH). Paris: Edition des Archives Contemporaines, 2011.

BOURDIEU, Pierre. A força do direito. Elementos para uma sociologia do campo jurídico. In: ___ . O poder simbólico. Rio de Janeiro: Bertrand, 1989. p. 209-235. 
CARVALHO, José Murilo. Cidadania no Brasil: o longo caminho. Rio de Janeiro: Civilização Brasileira, 2001.

COSSE, Isabella et al. (Org.). Infancia: políticas y saberes en Argentina y Brasil. Buenos Aires: Teseo, 2011.

FRONTANA, Isabel. Crianças e adolescentes nas ruas de São Paulo. São Paulo: Loyola, 1999.

FOUCAULT. Michel. História da sexualidade: a vontade de saber. Rio de Janeiro: Graal, 2007.v.1.

GREGORI, Maria Filomena. Viração: experiências de meninos nas ruas. São Paulo: Companhia das Letras, 2000.

LOUREIRO, José. A infância dos mortos (Pixote). São Paulo: Abril Cultural, 1984.

LIEBEL, Manfred. Enfants, droits et citoyenneté : faire émerger la perspective des enfants sur leurs droits. Paris: L'Harmattan, 2010.

MARSHALL, Thomas Humprey. Cidadania, classe social e status. Rio de Janeiro: Zahar, 1967.

MONACO, Gustavo Ferraz de Campos. A proteção da criança no cenário internacional. Belo Horizonte: Del Rey, 2005.

NAPOLITANO, Marcos. Cultura e poder no Brasil contemporâneo. Curitiba: Juruá, 2002.

OESTREICH, Joel E. UNICEF and the implementation of the Convention on the Rights of the Child. Global Governance, n. 4, p. 183-198, 1998.

OLIVEIRA, Fabiana. A criança e a infância nos documentos da ONU: a produção da criança como 'portadora de direitos' e a infância como 'capital humano do futuro'. 2008. Tese (Doutorado em Educação) - Universidade Federal de São Carlos, São Carlos, 2008.

PASSETTI, Edson. Crianças carentes e políticas públicas. In: DEL PRIORE, Mary. História das crianças no Brasil. São Paulo: Contexto, 2004. p. 347-375.

PINHEIRO, Ângela. Criança e adolescente no Brasil: porque o abismo entre a lei e a realidade. Fortaleza: Ed. UFC, 2006. 
RIZINNI, Irene. Crianças e menores: do pátrio poder ao pátrio dever. Um histórico da
legislação para a infância no Brasil. In: PILOTTI, Francisco; RIZINNI, Irene (Org.). A arte de governar crianças: a história das políticas sociais, da legislação e da assistência à infância no Brasil. São Paulo: Cortez, 2011. p. 97-149.

SANDRINI, Paulo Roberto. $O$ controle social da adolescência brasileira: gênese e sentidos do Estatuto da Criança e do Adolescente. 2009. Tese (Doutorado em Ciências Humanas) Universidade Federal de Santa Catarina, Florianópolis, 2009.

STEPAN, Alfred (Org.). Democratizando o Brasil. Rio de Janeiro: Paz e Terra, 1988.

VASSEUR, Paul. Protection de l'enfance et cohésion sociale du IVe au XXe siècle. Paris: L'Harmattan, 1999.

VOGEL, Arno. Do Estado ao Estatuto; propostas e vicissitudes da política de atendimento à infância e adolescência no Brasil contemporâneo. In: PILOTTI, Francisco; RIZZINI, Irene (Org.). A arte de governar crianças: a história das políticas sociais, da legislação e da assistência à infância no Brasil. São Paulo: Cortez, 2001. p. 287-221. 